\title{
Recognition of erosion risk areas using Neural Network Technology: an application to the Island of Corfu
}

\author{
Theodoros GOURNELOS ${ }^{1 *}$, Niki EVELPIDOU ${ }^{1 *}$, Anna KARKANI ${ }^{1}$, Eirini KARDARA ${ }^{1}$ \\ ${ }^{1}$ Faculty of Geology and Geoenvironment, National and Kapodistrian University of Athens, \\ Panepistimiopolis 15784, Athens, Greece
}

Received 14 July 2018; Revised 30 September 2018; Accepted 15 October 2018

*Correspondence to: Niki EVELPIDOU, e-mail: evelpidou@geol.uoa.gr

\begin{abstract}
There is a wide range of alternative approaches to study erosion processes. In this paper, we describe the construction of a model based on the interaction of Geographical Information System (GIS) and Artificial Neural Networks (ANN). The neural model uses supervised competitive learning process. The whole process begins with the digitization of collected data and the definition of the input variables, such as slope form and gradient, susceptibility to erosion and protective cover. The input variables are transformed into the erosion risk output variable using the neural model. The last stage is the development of a map of erosion risk zones. As a case study the island of Corfu (Ionian Sea, Greece) was chosen, which consists of lithologies very vulnerable to erosion and receives considerable amounts of rainfall, especially in comparison to the rest of Greece. Finally, the whole model was validated and its proper function was confirmed by field data observations.
\end{abstract}

KEYWORDS

neural networks; geomorphological process; erosion; Ionian Sea

\section{Introduction}

Erosion is a multistep geomorphological process. Weathering occurs before erosion. The thickness of the weathered material is interdependent of climatic variables such as temperature and precipitation, substratum rocks' susceptibility to erosion, vegetative cover and topography. The erosion process carries away the weathered material, however, there are many factors controlling that procedure. Erosion depends on geoenvironmental factors, such as climate, rock, morphology, land uses, weathered cap, and soil management, all of which determine its intensity and magnitude (Evelpidou et al., 2018).

The identification of erosion risk zones involves a series of different stages: field work, air-photos interpretation, satellite image analysis, digitization 
of geological, topographical and drainage system maps and finally the definition of input parameters. There is a vast literature concerning soil erosion or gravity movement processes with different approaches (Brundsen et al., 1975; Carrara et al., 1977; Malgot and Mahr, 1979; Ives and Messerli, 1981; Carrara, 1983; Morgan et al., 1984; Stocking et al., 1988; Carrara et al., 1991; Morgan, 1996; Marinos et al., 1997; Binagli et al., 1998; Stassopoulou et al., 1998; Gournelos et al., 2004).

Artificial Neural Networks (ANN) are characterized by a number of connected processing units, which have the ability to adapt their structure to multiple input data. The capabilities of learning and generalizing are an important asset for classification purposes. There are diverse architectures of ANN and different learning algorithms (Haykin, 1994). Artificial neural systems have been applied to a series of problems related to geosciences have shown a great potential. Some representative examples are those from multisource and hyperspectral data classification (Benediktsson et al., 1990), modelling of radioactive contaminated territories (Wu and Zhou, 1993), spatial simulation (Dowd, 1994), remote sensing imagery classification (Paola and Schowengerdt, 1995) and other similar applications (Kanevski et al., 1996; Wong et al., 2002; Licznar and Nearing, 2003). Recently similar researches have been applied for geotechnical and geology engineering (Ren et al., 2018; Arabi Aliabad et al., 2018), developing models for air pollution mining management (Asif et al., 2018), identifying rock strength correlations (Tariq et al., 2017). ANNs have also been employed for landslides susceptibility mapping (e.g. Yesilnacar and Topal, 2005; Melchiorre et al., 2008) and soil erosion studies (e.g. De la Rosa et al., 1999; Behrens et al., 2005).

In this context, the aim of this paper is to determine erosion risk areas on the island of Corfu, using Neural Network Technology. A simple competitive network, with four input and four competitive neurons, was constructed. The output of the system is a function of input vector, the weight matrix and the bias vector. Competitive learning processes are the outgrowth of the learning subspace method (LSM) (Kohonen, 1991), where the winner subspace is the closest of a given subspace. In its simplest form, a competitive network is made of a number of neurons, which receive the same vectorial data and by mutual interaction, one of the neurons wins (Kohonen, 1982; Rumelhart and Zipser, 1985). The election of the winner neuron is achieved by comparing the dot products of input vectors and the connections. The neuron with the highest value of dot product is the winner. When the inputs are normalised, they may be represented in the unit hypersphere. The learning procedure consists of progressive rotation of the weight vector to the closest cluster of input data (Gurney, 1997).

ANNs are computational structures, which can solve complex problems and currently are among the most successful algorithms for detection and classification of stream data (Ghorbani et al., 2018). In the present work, the definition of recognition zones was not very straightforward, due to the difficulties involved in defining precise values for the input variables.

\section{Study area}

Corfu is the second largest Ionian Island (Figs. 1, 2), covering an area of $583.4 \mathrm{~km}^{2}$, with a length of $61.65 \mathrm{~km}$ and a width of $26.58 \mathrm{~km}$ (maximum width). Geologically the island belongs to the external Ionian isopic zone as defined by Aubouin and Dercourt (1962), Caputo (1984), Underhill (1989) and Doutsos and Frydas (1994). The alpine structure mainly includes a Mesozoic carbonate platform, the progressive fracturing and deepening of which, is reflected on the pelagic sedimentation, followed by molassic sediments and Pliocene and Quaternary deposits (Fig. 3).

The climate of the island is Mediterranean, with cool summers and mild winters. However, its main characteristic is the high amount of rainfalls (mean annual precipitation more than $1.180 \mathrm{~mm}$ (Kandilis, 1991) (Fig. 4, Table 1). The climatic conditions in combination to the lithology of the island have contributed to the development, at some areas, of fertile soil layers with a rich vegetative cover, such as olives, vines, oranges, lemons, maize, cypress, pines and figs. 


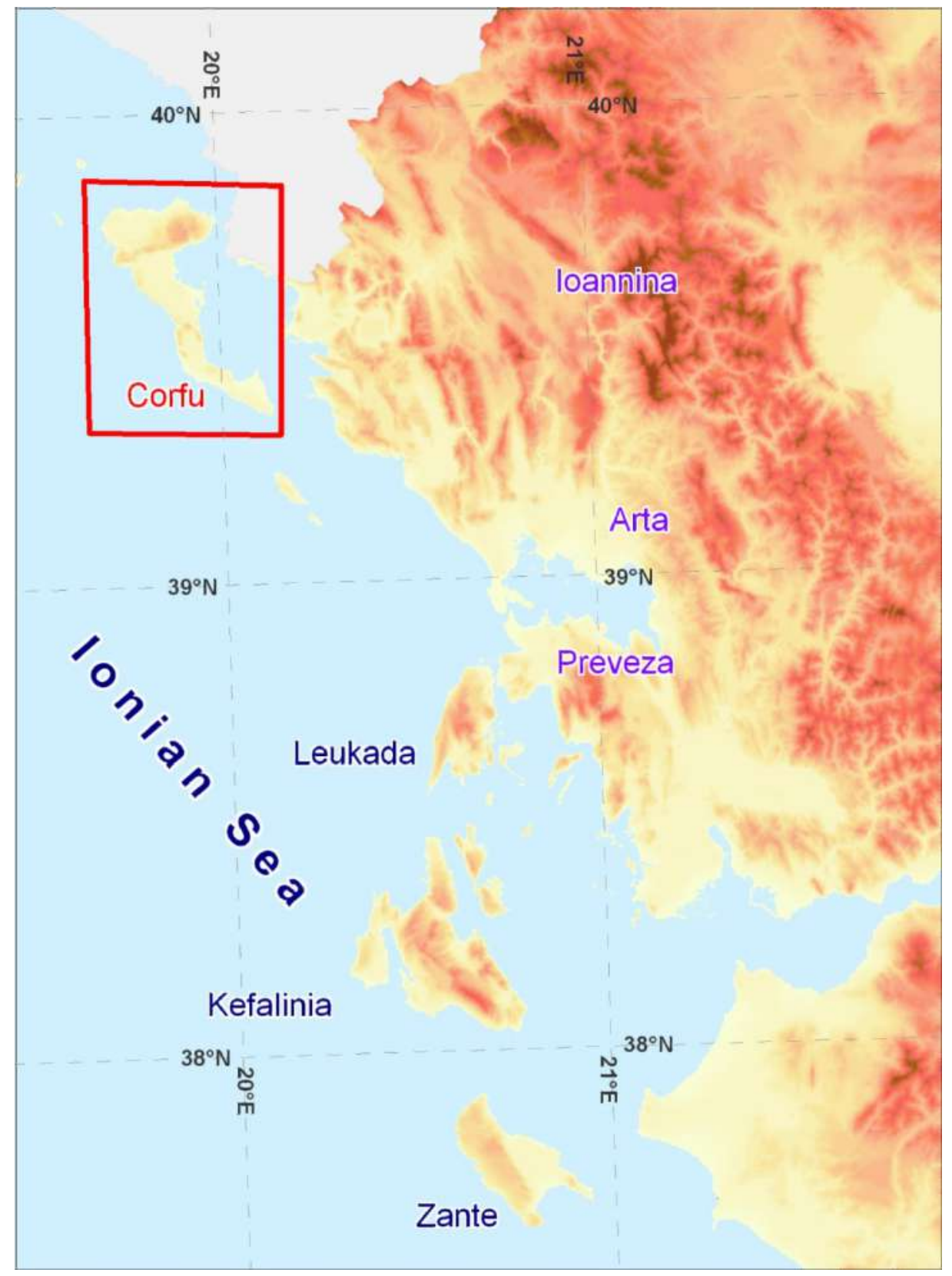

Figure 1 Location map of study area

Three geomorphological units may be distinguished on the island of Corfu:

1. The northern part, which includes the eastern part of Pantokrator limestone mountain (906 m) and the western part, which includes a sedimentary basin with Neogene sediments,

2. The central part, with smooth hilly landforms composed of Neogene and gypsum formations,

3. The southern part, with a low lying topography, and dominating lithologies of Neogene and Quaternary formations (Fig. 3).
The drainage system of Corfu is mainly characterised by a number of small streams, draining the Neogene formations, in the northern part, and the gypsum and Neogene sediments, in the central and southern part (Fig. 3).

On Corfu, apart from the marine and fluvial processes, the aeolian processes are also influential; this is indicated by the development of small dunes, especially along the banks of the Korisia Lake (Leontaris, 1977). 


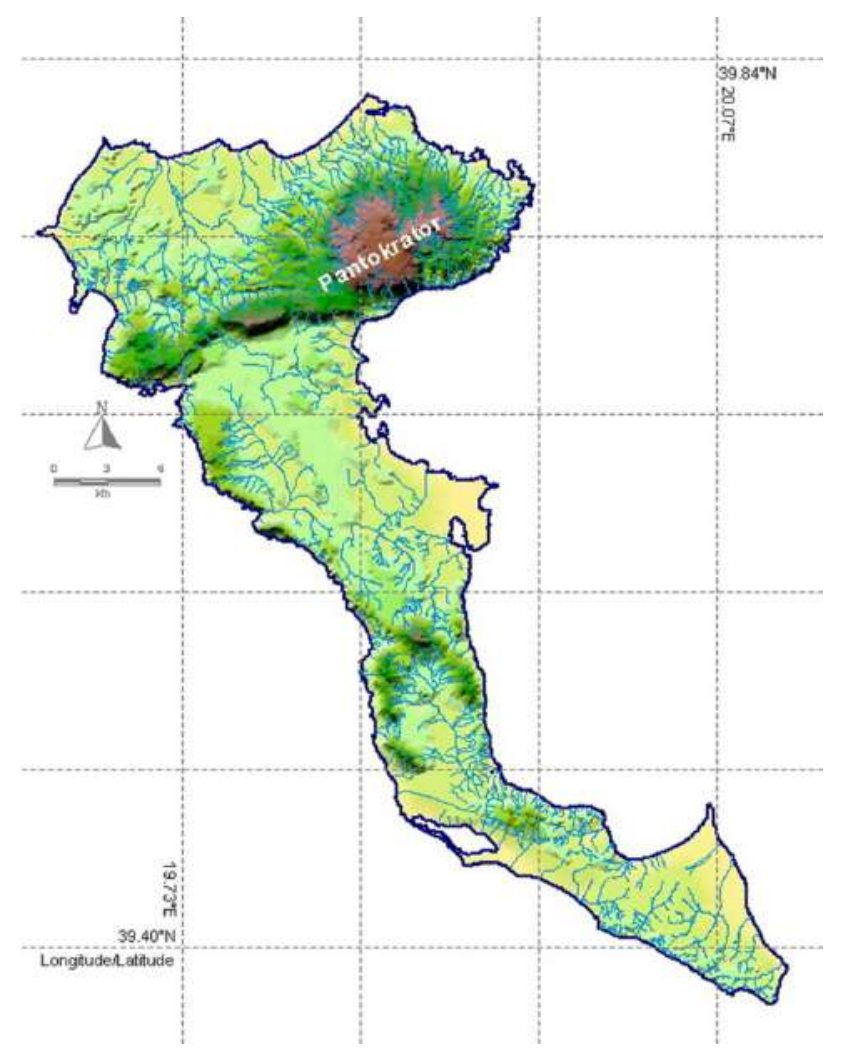

Figure 2 Topography and the drainage system of Corfu Island

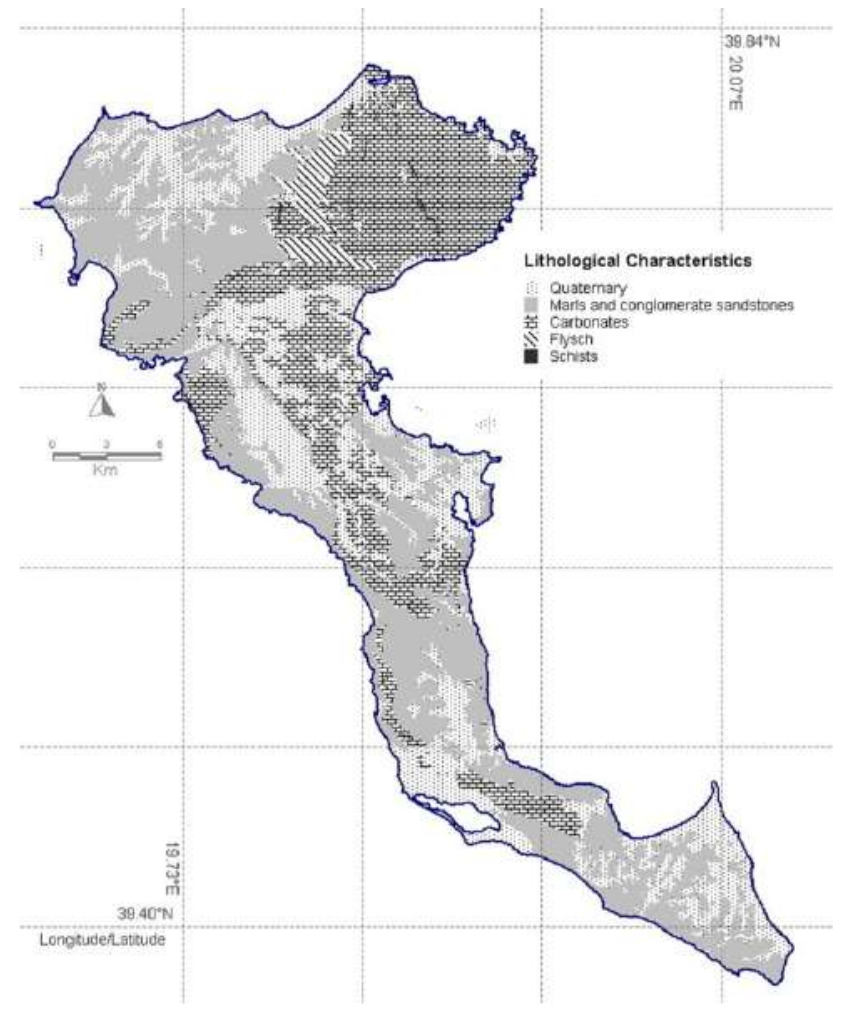

Figure 3 Lithological map of Corfu Island

\section{Methodology}

The methodology of this study was divided in several steps (Fig. 5). The process of developing a map of risk zones has been approached by using a loose coupling of GIS and Matlab softwares. The first step included the collection of data, which derived from existing geological maps (Institute of Geology and Mineral Exploration, 1970), topographic maps in scale 1:50 000 (Hellenic Army Geographical Service 1969, 1980), aerial photos in scale 1:33 000 and satellite images (Landsat 1980). Field work was also accomplished, in order to collect additional data, understand the processes taking place and select the appropriate input variables for the study area (geomorphology, slope gradient, vulnerability of erosion, protective cover).

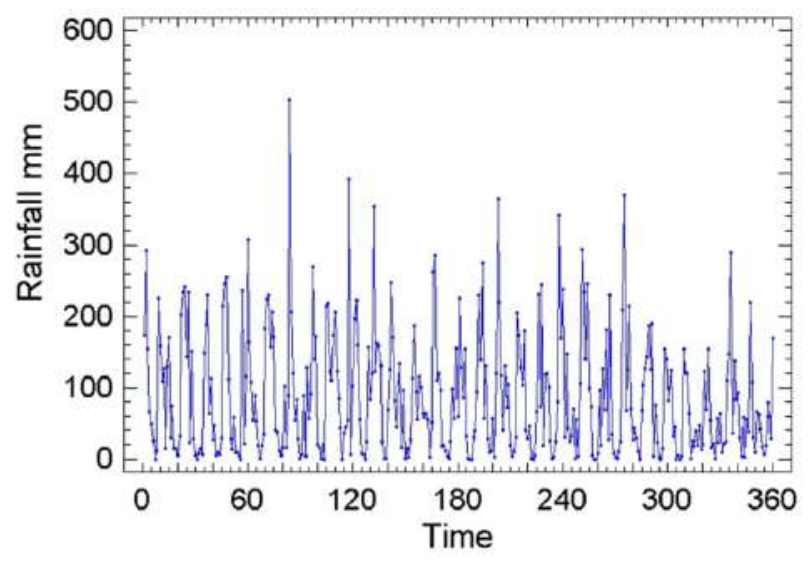

Figure 4 Time series plot for rainfall monthly data of Corfu

Table 1 Summary statistics of 30 years (1963-1992) rainfall in $\mathrm{mm}$ in Corfu island

\begin{tabular}{lc}
\hline Count & 360 \\
Average & 87.3167 \\
Variance & 7377.94 \\
Standard deviation & 85.8949 \\
Minimum & 0.0 \\
Range & 503.7 \\
Standard skewness & 9.86789 \\
Standard kurtosis & 6.82953 \\
\hline
\end{tabular}

The next step included the development of a GIS database, through the digitization of existing data. The input variables were processed by using a 
neural network system for studying the erosional depositional processes. Initially, the spatial database of all input variables has been developed in a GIS platform (MapInfo) and subsequently it was analysed, which led to the production of thematic maps. Values of the input variables were estimated for each elementary cell (a grid based database). The output variable at this final stage was erosion risk. In order to combine data layers, all the original data have been normalised by dividing them by their maximum value.

The input variables were applied to Matlab, after their normalisation, where the architecture of the ANN was developed. In order for an ANN to classify input vectors it must first be initialised, and then trained. The initialisation processes attribute values to the weight matrix. The training phase aims to the progressive minimisation of the distance between the winning neuron and the input vector.

Afterwards, a sensitivity analysis was carried out in order to test the proposed model to small perturbation of the input values. The analysis confirmed that minimal changes had no significant effect on the output variable. Following, the output classes of the ANN were imported in the GIS in order to produce the final output map. In this manner, the spatial capabilities of GIS and the classification power of the ANN system were fully exploited. It should be noted that, although the ANNs are considered to be black - box models, in this research the transparency of all the procedures and the continuous control of the results through field observations minimised this weakness.
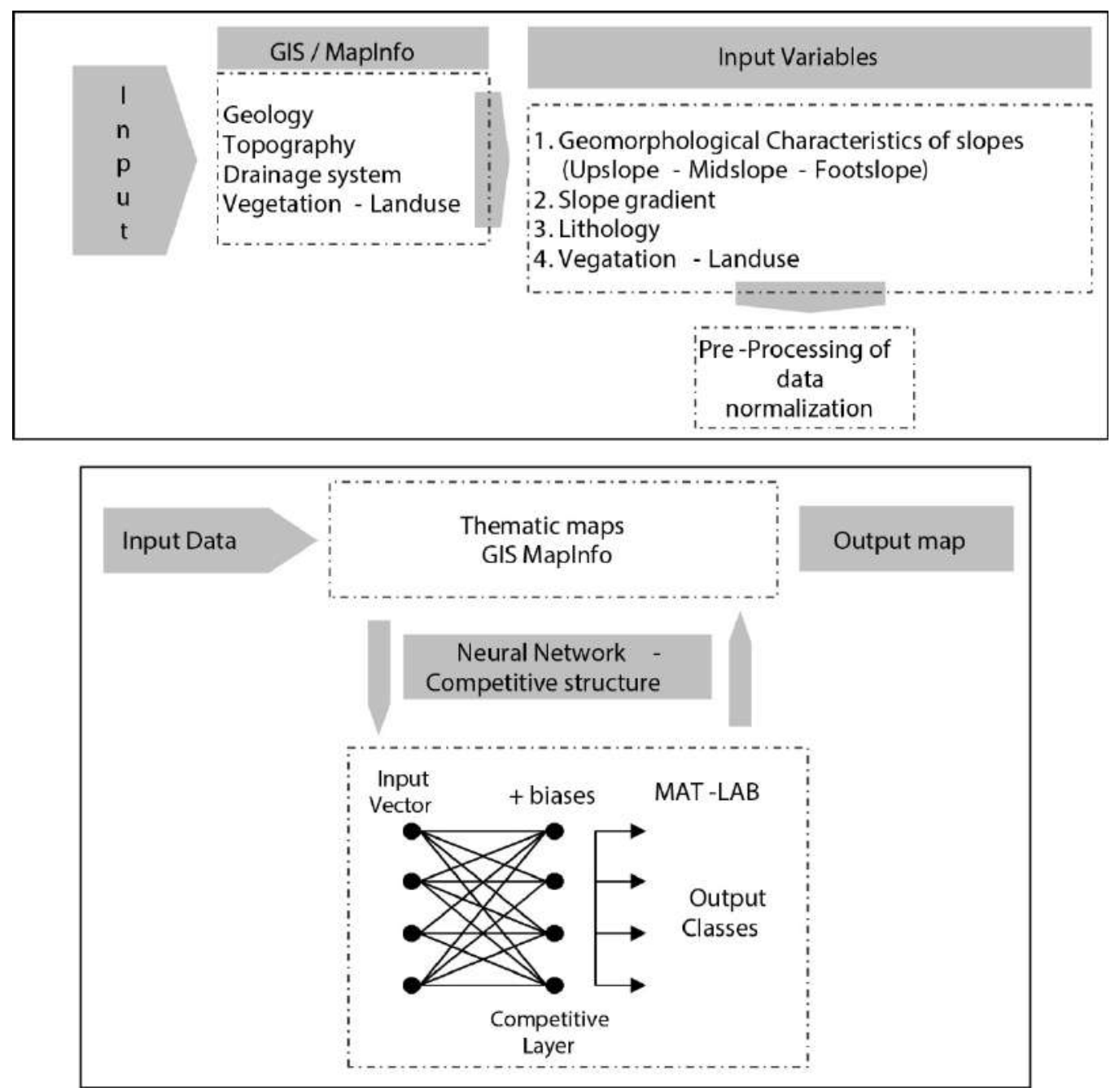

Figure $\mathbf{5}$ The methodological steps to produce the final output map: the erosion risk map 


\section{Results and Discussion}

The slope characteristics are influential. The geomorphology of slopes depends on the slope form, whose elements reflect the exogenous processes involved, such as weathering and erosion. A typical three division of a slope's elements has been adopted: upslope, mid-slope and footslope by scaling their property of favouring erosion processes. Upslope is confirmed as an area of relatively low erosion (0.2-0.3), mid-slope is dominated by high sediment transport (0.7-1) and footslope is mainly an area of deposition and therefore a very low degree of erosion is taking place (Table 2).

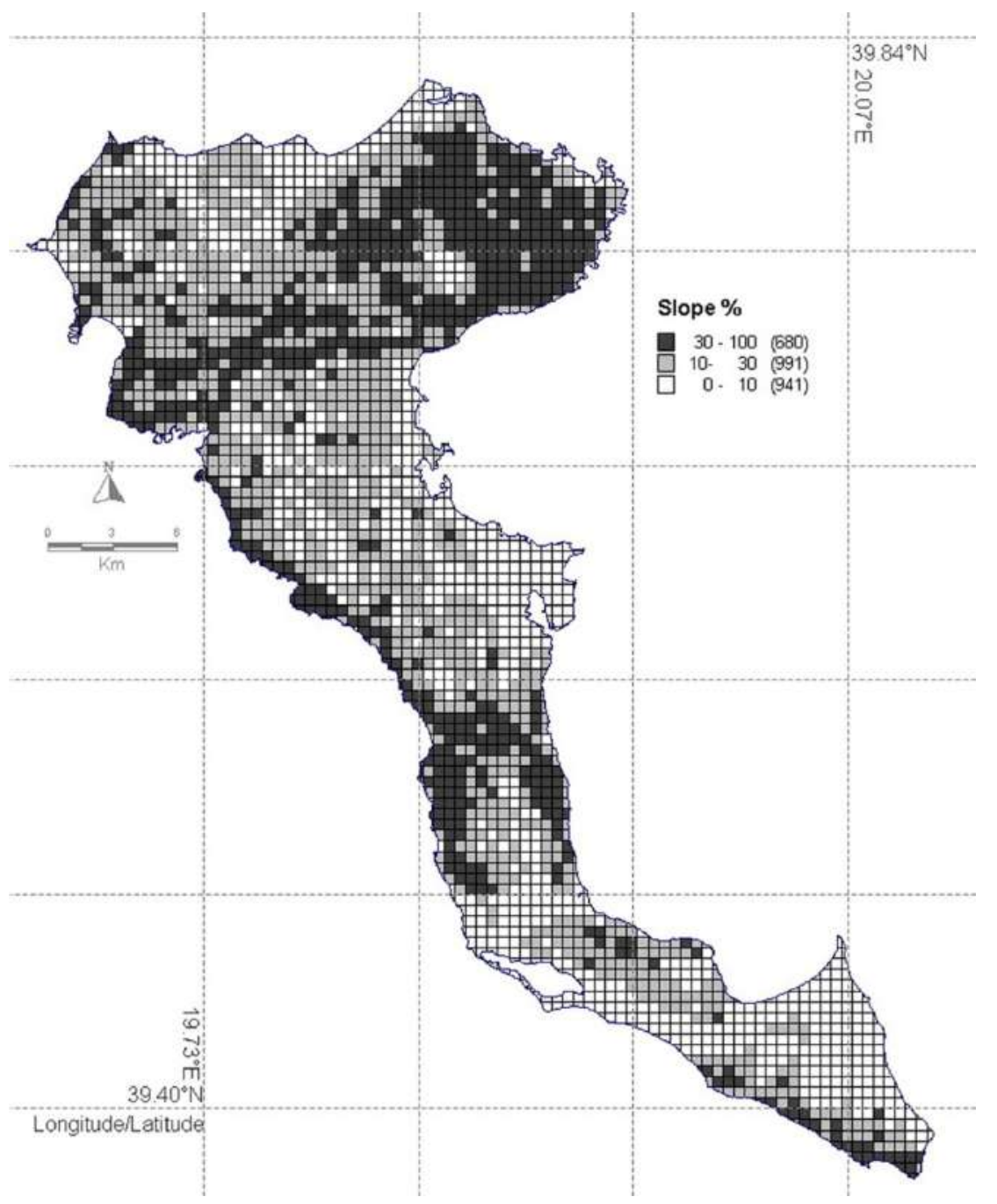

Figure 6 Slope gradient map of the Island of Corfu

The second processed variable was the morphological slope gradient. It is obvious that the slope steepness is critical for the intensity of erosion. Sediment removal is estimated as a function of divide distance multiplied by a power of slope gradient (Kirkby, 1978). Where slopes are steeper, gravitational movement and downslope sediment delivery are higher. In general, a linear or power relation between slope gradient and erosional products has been noted (Kirkby, 1969; Schumm, 1977). Slope steepness is critical for the intensity of erosion. Therefore, slope gradient was used as the second variable, and was calculated through the digital elevation model derived from GIS analysis. Three slope gradient classes were distinguished based on their steepness: high (0.7-1), medium (0.40.7 ) and low (0.1-0.4) (Fig. 6), (Table 2). 
Susceptibility to erosion is an important factor controlling the hardness of rocks, while the combination of rock's composition and texture, expressed by physical resistance, also affects erosion rates (Meybeck, 1987). The third variable, rock's susceptibility to erosion, was distinguished in three classes based on field observations and literature (Kuenen, 1956; Jensen and Painter, 1974; Selby, 1987). This variable is difficult to measure directly. Observations on the rocks' resistance to abrasion have resulted to a list of rocks sorted by descending order according to their resistance to erosion (Kuenen, 1956). On the other hand, Selby (1987) has proposed a rock mass strength classification and rating, to express the resistance to erosion. In the aforementioned classification limestones are more resistant to erosion than schists. The first attempt to assign susceptibility to erosion values on different rock types was made by Jensen and Painter (1974). For Corfu Island, low values for limestones (0.1-0.3), medium values for the schists $(0.3-0.6)$ and high values for the Neogene and Quaternary sediments (0.6-1), were adopted (Table 2).

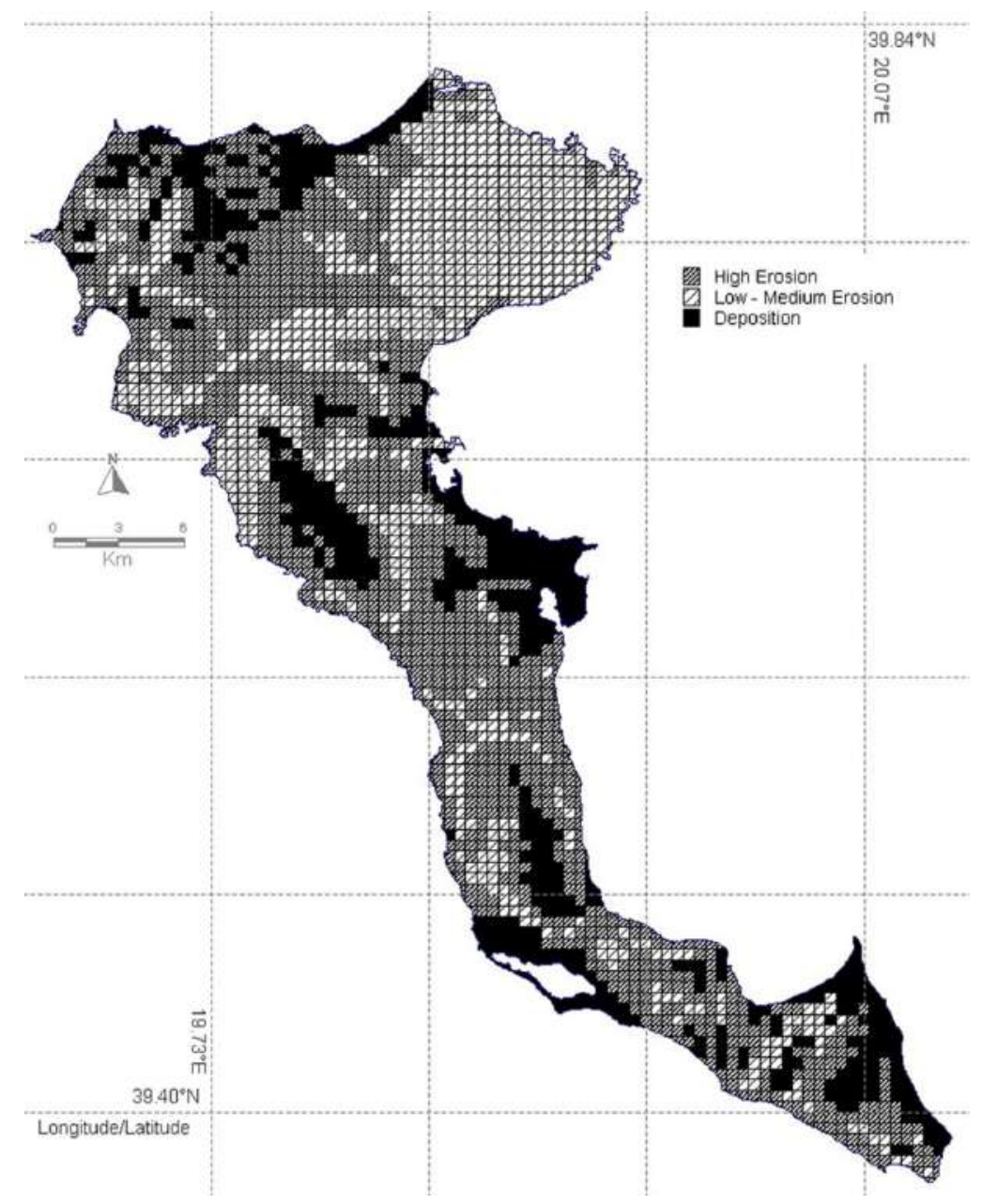

Figure 7 Erosion risk map of the Island of Corfu

The protective cover is closely linked to the soil characteristics and consequently to the ability of water for infiltration and run off. The protective cover variable was estimated mainly through data from vegetative cover, which protects the weathering material, by reducing the energy of the rain, controlling the soil thickness and the weathering mantle, increasing the infiltration capacity and limiting runoff. The vegetative cover of Corfu Island was divided in three classes: trees and bushes, agricultural lands and barren rocks. 
GOURNELOS et al. / Revista de Geomorfologie 20 (2018)

Table 2 Distribution values of the input and the output data sets

\begin{tabular}{|c|c|c|c|c|c|c|}
\hline \multicolumn{4}{|c|}{ Input Variables } & \multicolumn{3}{|c|}{ Output Variables } \\
\hline Type & Range & Count & Ratio \% & Erosion Risk & Count & Ratio \% \\
\hline \multirow{4}{*}{ Slope Form } & $\begin{array}{l}\text { Upslope } \\
0.2-0.3\end{array}$ & 481 & 18.417 & High & 910 & 34.839 \\
\hline & $\begin{array}{l}\text { Midslope } \\
0.7-1\end{array}$ & 1515 & 58 & Medium - Low & 1059 & 40.544 \\
\hline & $\begin{array}{l}\text { Footslope } \\
0-0.1\end{array}$ & 616 & 23.583 & Deposition & 643 & 24.617 \\
\hline & $\begin{array}{l}\text { High } \\
30-100 \% \\
0.7-1 \\
\text { Medium }\end{array}$ & 5 & 0.19 & & & \\
\hline \multirow[t]{2}{*}{ Slope Gradient } & $\begin{array}{l}10-30 \% \\
0.4-0.7 \\
\text { Low }\end{array}$ & 261 & 9.994 & & & \\
\hline & $\begin{array}{l}0-10 \% \\
0.1-0.4\end{array}$ & 2346 & 89.816 & & & \\
\hline \multirow{3}{*}{ Lithology } & High to erosion $0.6-1$ & 1696 & 64.932 & & & \\
\hline & $\begin{array}{l}\text { Medium to erosion } \\
0.3-0.6\end{array}$ & 385 & 14.739 & & & \\
\hline & Low to erosion $0.1-0.3$ & 531 & 20.329 & & & \\
\hline \multirow{3}{*}{ Vegetation Landuse } & $\begin{array}{l}\text { Trees and Bushes } \\
0.1-0.2\end{array}$ & 868 & 33.232 & & & \\
\hline & Agricultural land $0.2-0.7$ & 1645 & 62.978 & & & \\
\hline & $\begin{array}{l}\text { Barren rocks } \\
0.7-1\end{array}$ & 99 & 3.79 & & & \\
\hline
\end{tabular}

These classes have been empirically valued according to their contribution to the erosional processes, as follows: $0.1-0.2$ for trees and bushes, $0.2-$ 0.7 for agricultural lands and $0.7-1$ for barren rocks (Table 2).

The four input variables using the ANN model were transformed into the output variable, which was the erosion risk (Figs. 5, 7). In the map of Figure 7 three classes of geomorphological processes may be distinguished along with three zones of high erosion, medium and low erosion and deposition.

It is obvious that high erosion zones are located where very susceptible to erosion rocks are present (Neogene or Quaternary deposits), slope gradients are relatively high and mid-slopes exist. Low to medium erosion zones are found in areas of schists or limestones, with medium slope gradients and mainly on upslopes or in mid-slopes.

Finally, deposition zones are restricted to footslope areas. The aforementioned results have been further confirmed through field observations on Corfu Island.

\section{Conclusions}

Artificial Neural Networks and GIS may be combined to produce erosion risk maps. The implementation of these procedures has been achieved by loose coupling of the GIS platform (MapInfo) and a constructed ANN (Mat-Lab). This application was used to map the erosion risk zones of Corfu Island. Our results show that high erosion risk areas are located on the northwestern and central part of the 
island, while low to medium risk areas are mainly located in the northeastern part. Depositional zones are restricted mainly in coastal areas. The analysis of the zones of high erosion risk may result to the recognition of areas where land degradation processes are very active and highlight areas, where measures are needed against further soil loss and superficial deposits. This type of model is relatively easy to develop, is rapidly adapted to input data and is very easy to generalize.

\section{References}

Arabi Aliabad F, Shojaei S, Zare M, Ekhtesasi MR, 2018. Assessment of the fuzzy ARTMAP neural network method performance in geological mapping using satellite images and Boolean logic. International Journal of Environmental Science and Technology, 110. DOI: https://doi.org/10.1007/s13762-018-1795-7

Aubouin J, Dercourt J. 1962. Zone preapulienne, zone ionienne et zone du Gavrovo en Peloponnese occidentale. Bulletin de la Societe Geologique de France, 4(6): 785-794, France, Paris.

Asif Z, Chen Z, Zhu ZH. 2018. An integrated life cycle inventory and artificial neural network model for mining air pollution management. International Journal of Environmental Science and Technology, 1-10. DOI: https://doi.org/10.1007/s13762-018-1813-9

Behrens T, Förster $H$, Scholten T, Steinrücken U, Spies ED, Goldschmitt M. 2005. Digital soil mapping using artificial neural networks. Journal of plant nutrition and soil science, 168(1): 21-33.

Benediktsson JA, Swain PH, Ersoy OK. 1990. Multisource data classification and feature extraction with neural networks. IEEE Transaction on Geoscience and Remote Sensing, 28: 540-552.

Binagli E, Luzi L, Madella P, Pergalani F, Rampini A. 1998. Slope Instability Zonation: a Comparison between Certainty Factor and Fuzzy Dempster-Shafer Approaches. Natural Hazards, 17: 77-97.

Brundsen D, Doornkamp JC, Fookes PG, Jones DKC, Kelly $\mathrm{JMH}$. 1975. Large scale geomorphological mapping and highway engineering design. Quarterly Journal of Engineering Geology, 8: 227-253.

Caputo R. 1984. Geologia della zona trascorrente di Corfu (Grecia). PhD Thesis, Ferrara University, 130 p. (unpublished).

Carrara A, Pugliese-Garratelli E, Merenda L. 1977. Computer based data bank and statistical analysis of slope stability phenomena. Zeitschrift fur Geomorphologie NF, 21(2): 187-222.
Carrara A, Cardinali M, Detti, R, Guzzetti, F, Pasqui V, Reichenbach P. 1991. GIS techniques and statistical models in evaluating landslide hazard. Earth Surface Processes and Landforms, 16(5): 427-455.

Carrara A. 1983. Multivariate models for landslides hazard evaluation. Mathematical Geology, 15(3): 403-427.

De la Rosa D, Mayol F, Moreno JA, Bonsón T, Lozano S. 1999. An expert system/neural network model (ImpelERO) for evaluating agricultural soil erosion in Andalucia region, southern Spain. Agriculture, Ecosystems \& Environment, 73(3): 211-226.

Doutsos Th, Frydas D. 1994. The Corfu thrust (Greece). Comptes Rendus Académie des Sciences, 318(2): 659-666.

Dowd PA. 1994. The use of neural networks for spatial simulation. In: Dimitrakopoulos R. (ed.): Geostatistics for the next century. Springer, Dordrecht, 173-184.

Evelpidou N, Kampolis I, Karkani A. 2018. Geomorphic Features Associated with Erosion. In: Singh R, Bartlett D. (eds.): Natural Hazards Earthquakes, Volcanoes, and Landslides. CRC Press-Taylor \& Francis, Boca Raton, 205-231.

Ghorbani S, Barari M, Hoseini M. 2018. Presenting a new method to improve the detection of micro-seismic events. Environmental Monitoring and Assessment, 190: 464. DOI: https://doi.org/10.1007/s10661-0186837-6

Gournelos Th, Evelpidou N, Vassilopoulos A. 2004. Developing an Erosion risk map using soft computing methods (case study at Sifnos island). Natural Hazards, 31(1): 39-61.

Gurney K. 1997. An introduction to neural networks. Taylor \& Francis group, Bristol, $288 \mathrm{p}$.

Haykin S. 1994. Neural networks: a comprehensive foundation. Macmillan, New York.

Hellenic Army Geographical Service, 1969. Topographical map, Karousades Sheet, Scale 1:50.000.

Hellenic Army Geographical Service, 1980. Topographical maps, Scale 1:5000.

Institute of Geology and Mineral Exploration, 1970. Geological Map, North Corfu Sheet, Scale 1:50 000.

Ives JD, Mersserli B. 1981. Mountain hazard mapping in Nepal, Introduction to an applied mountain research project. Mountain Research and Development, 1(3-4): 223-230.

Jensen JM, Painter RB. 1974. Predicting sediment yield from climate and topography. Journal of Hydrology, 21: $371-380$.

Kandilis F. 1991. Rainfall height tendency in Greece during the last 30 years 1960-1989. Publications of Climato/ogy Laboratoty, University of Athens, 1-7.

Kanevski M, Arutyunyan R, Bolshov L, Demianov V, Maignan M. 1996. Artificial Neural Networks and 
Spatial Estimation of Chernobyl Fallout. Geoinformatics, 7(1-2): 5-11.

Kirkby MJ. 1969. Infiltration, throughflow and overland flow. In: Chorley RJ. (ed.): Water, Earth and Man. Methuen, London, 215-227.

Kirkby MJ. 1978. Implications for sediment transport. In: Kirkby MJ. (ed.): Hillslope Hydrology. John Wiley, Chichester, 325-340.

Kohonen T. 1982. Self-organized formation of topologically correct feature maps. Biological Cybernetics, 43: 59-69.

Kohonen T. 1991. Self-organizing maps: optimization approaches. Artificial Neural Networks, 2: 981-990.

Kuenen PH 1956. Rolling by current (Pt) 2 of Experimental abrasion of pebbles. Journal of Geology, 64: 336-368.

Leontaris S. 1977. Sur la provenance et l'evolution des dunes de Corfu du sud et sur leur relation avec le lac de Corission. Proceedings of the Academy of Athens, 51: 522-539.

Licznar P, Nearing MA. 2003. Artificial neural networks of soil erosion and runoff prediction at the plot scale. Catena, 51 (2): 89-114.

Malgot J, Mahr T. 1979. Engineering geological mapping of the West Carpathian landslide areas. Bulletin of the International Association of Engineering Geology, 19: 116-121.

Marinos PG, Plessas SP, Valadaki-Plessa K. 1997. Erosion risk maps for the greater Athens region and a G.I.S. based processing of data. In: Marinos PG, Koukis GC, Tsiambaos GC, Stournaras GC. (eds.): Engineering and the Environment. Balkema, Rotterdam, 1353 p.

Melchiorre C, Matteucci M, Azzoni A, Zanchi A. 2008. Artificial neural networks and cluster analysis in landslide susceptibility zonation. Geomorphology, 94(34): $379-400$.

Meybeck M. 1987. Global chemical weathering of surficial rocks estimated from river dissolved loads. American Journal of Science, 287: 401-428.

Morgan RPC, Morgan DDV, Finney HJ. 1984. A predictive model for the assessment of soil erosion risk. Journal of Agricultural Engineering Research, 30: 245-53.

Morgan RPC. 1996. Soil erosion and conservation. 2nd edition Longman.
Paola JD, Schowengerdt RA. 1995. A review and analysis of backpropagation neural networks for classification of remotely sensed multispectral imagery. International Journal of Remote Sensing, 16: 3033-3058.

Ren Q, Wang G, Li M, Han S. 2018. Prediction of Rock Compressive Strength Using Machine Learning Algorithms Based on Spectrum Analysis of Geological Hammer. Geotechnical and Geological Engineering, 1-15. DOI: 10.1007/s10706-018-0624-6

Rumelhart D, Zipser D. 1985. Feature discovery by competitive learning. Cognitive Science, 9: 75-112.

Schumm SA. 1977. The fluvial system. Wiley, New York, $338 \mathrm{p}$.

Selby MJ. 1987. Rock slopes. In: Anderson MG, Richards KS. (eds.): Slope Stability. Wiley, Chichester, 475-504.

Stassopoulou, A, Petrou M, Kittler J. 1998. Application of a Bayesian network in a GIS based decision making system. Intenational Journal of Geographical Information Science, 12(1): 23-45.

Stocking M, Chakela Q, Elwell H. 1988. An Improved Methodology for Erosion Hazard Mapping Part I: The Technique. Geografiska Annaler Series A, Physical Geography, 70(3): 169-180.

Tariq Z, Elkatatny S, Mahmoud M, Ali AZ. 2017. A new technique to develop rock strength correlation using artificial intelligence tools. SPE Reservoir Characterisation and Simulation Conference and Exhibition, 810 May, Abu Dhabi, UAE.

DOI: https://doi.org/10.2118/186062-MS

Underhill JR. 1989. Late Cenozoic deformation of the Hellenide forcland, Western Greece. Geological Society of America Bulletin, 101: 613-634.

Wong P, Aminzadeh F, Nikravesh M. (eds.) 2002. Soft computing for reservoir characterization and mode/ling. Springer Verlag, Heidelberg, $586 \mathrm{p}$.

Wu X, Zhou Y. 1993. Reserve Estimation using Neural network techniques. Computers \& Geosciences, 19(4): 567-57.

Yesilnacar E, Topal T. 2005. Landslide susceptibility mapping: a comparison of logistic regression and neural networks methods in a medium scale study, Hendek region (Turkey). Engineering Geology, 79(3-4): 251266. 